\section{Quantitative Assessment of the Association between Polymorphisms in Osteoprotegerin and Bone Mineral Density}

\section{Abstract}

Background: Low bone mineral density (BMD) predisposes to osteoporosis and elevated risk of fractures. Osteoprotegerin is a soluble molecule associated to metabolism of bone tissue with inhibition of osteoclast-differentiation. Several studies determined the relation among polymorphisms in osteoprotegerin gene and low BMD, but the results are contradictory, so an evaluation about these polymorphisms is necessary. This study carried out a meta-analysis to four polymorphisms in osteoprotegerin gene (A163G, G1181C, T950C, T245G).

Methods: A search in literature was made to identify studies with relevant information. The data was extracted by two investigators independently, following a standardized form. The statistical software Review Manager version 5.2 was used to calculation of heterogeneity $\left(I^{2}\right)$, Odds Ratio (OR) and Funnel plots with $P<0.05$.

Results: Nineteen papers with twenty-one eligible studies with 5,120 patients and 4,386 controls were identified. G allele was associated to case group in A163G, G1181C and T245G polymorphisms (OR = 1.27, 95\% Cl 1.10, 1.46, $P=0.0010 ; \mathrm{OR}=1.25,95 \% \mathrm{Cl} 1.14,1.37$, $P<0.00001 ; \mathrm{OR}=1.24,95 \% \mathrm{Cl} 1.05,1.48, P=0.01$, respectively). In T950C polymorphism, $T$ allele neither $C$ allele was associated to risk of bone low mineral density. No bias of publication was found in this analysis.
Felipe Rodolfo Pereira da Silva', Any Carolina Cardoso Guimarães Vasconcelos², Geofabio Sucupira Casimiro ${ }^{3}$, Larissa dos Santos Pessoa', Antonio de Pádua Rocha Nóbrega Neto', Daniel Fernando Pereira Vasconcelos ${ }^{1 *}$

1 Federal University of Piaui, Av. São Sebastião, $n^{\circ}$ 2819, Reis Veloso, CEP 64204-035, Parnaíba, PI, Brazil.

2 Mauricio Nassau College, BR 343 Km 7,5 S/N, Floriópolis, Parnaiba, PI, Brazil.

3 Federal University of Campina Grande, Av. Sergio Moreira de Figueiredo, Casas Populares, S/N, 58900-000, Cajazeiras, PB, Brazil.

Contact information:

Daniel Fernando Pereira Vasconcelos Universidade Federal do Piauí - UFPI; Campus Ministro Reis Veloso; Av. São Sebastião, 2819, Reis Veloso

”vasconcelos@ufpi.edu.br

Keywords

Osteoclast, Alleles, Metaanalysis, Osteoporosis, Genetic Variation. 
Conclusion: This meta-analysis with 5,120 patients with low bone mineral density and 4,386 controls showed significant association among $G$ alleles in A163G, G1181C and T245G polymorphism and increased risk of low BMD, T950C polymorphism was not significantly associated to risk of low bone mineral density.

\section{Introduction}

Low bone mineral density is a clinical condition present in common diseases such as osteoporosis, and is the single best predictor of osteoporotic fractures and a valuable tool in the evaluation of fracture risk [1].

Studies on twins and on families have shown that as much as $70-80 \%$ of the inter-individual variance in bone mineral density at the spine and hip is genetically determined. The genetic contribution to bone mass was observed even into old age, indicating that genes regulate both peak bone mass as well as the rate of bone loss [2].

Several genes have been evaluated to assess their involvement in low BMD $[3,4,5]$ and the osteoprotegerin (OPG) gene is one of the most important candidate genes for osteoporosis, suggested to be associated with low BMD and risk of fractures [6]

Osteoprotegerin is an endogenous receptor antagonist of receptor activator of nuclear factor- $\kappa \mathrm{B}$ ligant (RANKL) that is a cytokine responsible for osteoclast differentiation [7]. OPG consequently blocks the effects of RANKL.

The recent studies focus in four polymorphisms in OPG gene: A163G, G1181C, T950C and T245G. These variations already were associated to low Bone Mineral Density [8] and osteoporosis [9]. However the results from others studies $[10,11]$ are contradictories and a better approach forward the association of these polymorphisms is required.

Thus, the aim of this study was to evaluate the influence of the aforementioned polymorphisms and the real risk of low BMD by means of a metaanalysis.

\section{Methods}

\section{Strategy of search}

A systematic search in literature was performed by three investigators in the electronic biomedical and education databases (Cochrane Library, Google Scholar, MEDLINE and PubMed) to studies published before March 11, 2015 and addressing the association of A163G, G1181C, T245G and T950C polymorphisms in OPG gene and Low Bone Mineral Density. The following combined keywords were used to retrieve the literature: ("osteoprotegerin" or "OPG") and ("polymorphism" or "SNP" or "A163G" or "G1181C" or "T245G" or "T950C") and ("low bone mineral density" or "bone mineral density"). No language restriction was placed on the search and all citations of studies were screened to identify additional potential studies.

\section{Inclusion criteria}

Articles were included in current meta-analysis if the studies met all the following criteria: (1) Eva- 
luation of the polymorphisms cited and risk of low bone mineral density; (2) Studies are case/control design; (3) Genotype frequency documented; (4) Diagnosis of low bone mineral density confirmed through radiographic findings and clinical evaluation; (5) The distributions of alleles in study meet in Hardy-Weinberg Equilibrium (HWE). Studies which did not bring sufficient information about genotype or allelic frequencies or did not respect any point these criteria were excluded.

\section{Data extraction}

Two investigators (FR and AP) independently reviewed all studies and extracted the data using a standardized form. Data were collected on the authors, year of publication, study design (case, control), number of cases and controls, the polymorphism or polymorphisms evaluated, genotyping method and subject type in study.

\section{Statistical analysis}

The statistical analysis of data was performed with use of Review Manager version 5.2 software (RevMan, Nordic Cochrane Centre, The Cochrane
Collaboration, 2012).

The chi-squared based Q statistic test (/2) was used to assess the presence of heterogeneity. When heterogeneity was not significant $\left(I^{2}<50 \%, P>0.05\right)$ the Fixed-effects model was used to estimate the pooled Odds Ratio (OR), when heterogeneity was significant $\left(I^{2}>50 \%, P<0.05\right)$ and the studies that case this value could not excluded, the Randomeffects model was used. Both methods the $P$ value $<0.05$ was considered statistically significant. Funnel plots (with $P<0.05$ ) were used to examine heterogeneity and the publications bias of reported associations and all of data in studies were dichotomous data expressed as OR with $95 \%$ of confidence intervals $(\mathrm{Cl})$ to assess the association between polymorphisms in OPG gene and low bone mineral density.

\section{Results}

\section{Characteristics of eligible studies}

Nineteen papers with twenty-one eligible casecontrol [3,12-29] studies were identified at finish of search in literature as informed in figure 1. In ove-

Figure 1: Flow diagram for inclusion of studies in this meta-analysis.
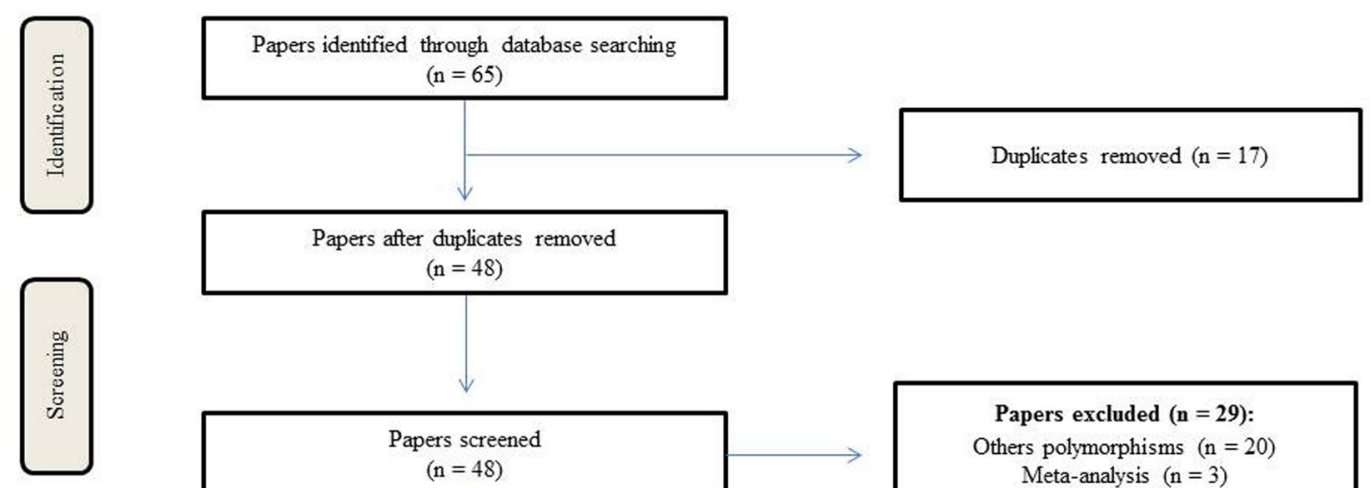

$(n=48)$
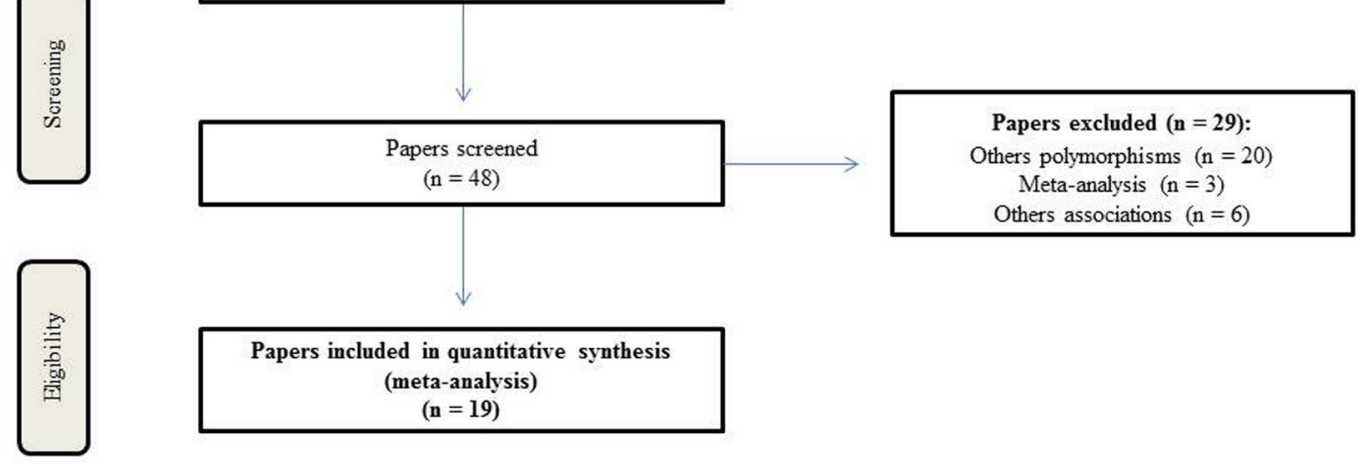

Papers included in quantitative synthesis

(meta-analysis)

$(\mathrm{n}=19)$ 
rall, 5,120 cases and 4,386 controls were included in this meta-analysis. All studies involved women and five from twenty-one studies involved men and women. The basic characteristics of studies were brought in table 1 and all of the genotype and allelic frequencies in case and control groups followed HWE (data no shown).

\section{Association between A163G polymorphism and risk of low bone mineral density}

Ten studies evaluated the A163G polymorphism in patients with low BMD but one study was exclu- ded because its data carried out elevated heterogeneity in allele evaluations [18]. The meta-analysis of nine studies showed $G$ allele was associated to case group $(\mathrm{OR}=1.27,95 \% \mathrm{Cl} 1.10,1.46, P=0.0010)$ (Figure 2-A). The evaluation of genotype combinations was carried out and evidenced elevated association between GG genotype and patients case (Table 2).

\section{Association between G1181 polymorphism and risk of low bone mineral density}

The meta-analysis of alleles from eleven studies in which one study [14] was excluded because ele-

Figure 2: (A) Meta-analysis of $G$ allele in A163G polymorphism. (B) Meta-analysis of $G$ allele in G1181C polymorphism.

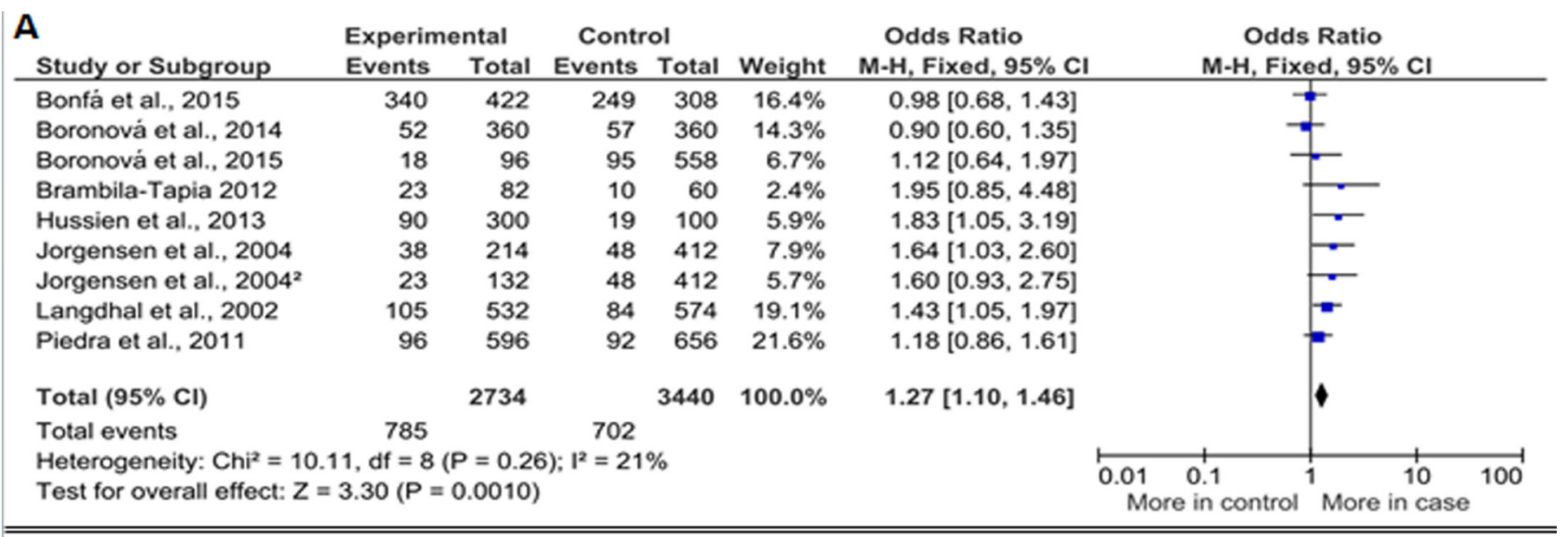

\begin{tabular}{|c|c|c|c|c|c|c|c|c|}
\hline \multicolumn{9}{|l|}{ B } \\
\hline \multirow[b]{2}{*}{ Study or Subgroup } & \multicolumn{2}{|c|}{ Experimental } & \multicolumn{2}{|c|}{ Control } & \multirow[b]{2}{*}{ Weight } & \multirow{2}{*}{$\begin{array}{c}\text { Odds Ratio } \\
\text { M-H, Fixed, } 95 \% \mathrm{Cl}\end{array}$} & \multirow{2}{*}{\multicolumn{2}{|c|}{$\begin{array}{c}\text { Odds Ratio } \\
\text { M-H, Fixed, } 95 \% \mathrm{Cl}\end{array}$}} \\
\hline & Events & Total & Events & Total & & & & \\
\hline Bonfá et al., 2015 & 255 & 422 & 182 & 308 & $9.9 \%$ & $1.06[0.78,1.43]$ & & - \\
\hline Boronová et al., 2015 & 52 & 96 & 283 & 558 & $4.5 \%$ & $1.15[0.74,1.77]$ & & - \\
\hline Hsu et al., 2006 & 443 & 570 & 427 & 580 & $11.2 \%$ & $1.25[0.95,1.64]$ & & - \\
\hline Kim et al., 2007 & 340 & 444 & 234 & 326 & $7.5 \%$ & $1.29[0.93,1.78]$ & & - \\
\hline Langdhal et al., 2002 & 244 & 532 & 246 & 578 & $15.2 \%$ & $1.14[0.90,1.45]$ & & $=$ \\
\hline Mecej-Bedrac et al., 2009 & 235 & 478 & 190 & 456 & $11.8 \%$ & $1.35[1.05,1.75]$ & & $=$ \\
\hline Mecej-Bedrac et al., 2011 & 240 & 486 & 196 & 470 & $12.0 \%$ & $1.36[1.06,1.76]$ & & - \\
\hline Piedra et al., 2011 & 295 & 596 & 326 & 656 & $18.6 \%$ & $0.99[0.79,1.24]$ & & \\
\hline Vidal et al., 2006 & 202 & 362 & 98 & 238 & $6.2 \%$ & $1.80[1.30,2.51]$ & & - \\
\hline Zhao et al., 2005 & 210 & 268 & 92 & 142 & $3.1 \%$ & $1.97[1.25,3.09]$ & & - \\
\hline Total $(95 \% \mathrm{Cl})$ & & 4254 & & 4312 & $100.0 \%$ & $1.25[1.14,1.37]$ & & 1 \\
\hline Total events & 2516 & & 2274 & & & & & \\
\hline \multicolumn{7}{|c|}{ Heterogeneity: $\mathrm{Ch}^{2}=15.50$, df $=9(P=0.08) ; 1^{2}=42 \%$} & 0.01 & $10 \quad 100$ \\
\hline Test for overall effect: $Z=$ & $79(P<0$. & & & & & & More in control & More in case \\
\hline
\end{tabular}


Table 1. Characteristic of studies selected to this meta-analysis.

\begin{tabular}{|c|c|c|c|c|c|c|}
\hline FIRST AUTHOR & $\begin{array}{l}\text { STUDY } \\
\text { DESIGNE }\end{array}$ & $\begin{array}{l}\text { SIMPLE } \\
\text { SIZE }\end{array}$ & AGE (YEARS) & $\begin{array}{l}\text { DETECTION } \\
\text { METHOD }\end{array}$ & MUTATION SITE & $\begin{array}{l}\text { SUBJECT } \\
\text { TYPE }\end{array}$ \\
\hline BONFÁ et al., 2015 & CASE/CONTROL & $221 / 154$ & $33.3 \pm 7.3 / 32.1 \pm 7.2$ & TaqMan & A163G - G1181C - T245G & WOMEN \\
\hline BORONOVA et al,. 2014 & CASE/CONTROL & $200 / 200$ & DATA NO SHOWN & TaqMan & $\mathrm{T} 245 \mathrm{G}$ & WOMEN \\
\hline BORONOVA et al., 2014 & CASE/CONTROL & $180 / 180$ & DATA NO SHOWN & TaqMan & A163G - G1181C & WOMEN \\
\hline BORONOVA et al., 2015 & CASE/CONTROL & $48 / 279$ & $66.92 \pm 9.63 / 64.69 \pm 9.18$ & TaqMan & A163G - G1181C - T245G & WOMEN \\
\hline BRADSTROM et al., 2004 & CASE/CONTROL & $361 / 497$ & DATA NO SHOWN & TaqMan & T950C & WOMEN \\
\hline BRANDSTROM et al., 2004 & CASE/CONTROL & $295 / 497$ & $75.2 \pm 0.16 / 75.2 \pm 0.16$ & TaqMan & T950C & WOMEN \\
\hline DINCEL et al., 2008 & CASE/CONTROL & $19 / 21$ & $74.47 \pm 8.91 / 75.47 \pm 7.44$ & HIBRIDIZATION & A163G -T245G & $\begin{array}{c}\text { WOMEN } \\
\text { MEN }\end{array}$ \\
\hline HSU et al., 2006 & CASE/CONTROL & $285 / 290$ & $47.8 \pm 7.1 / 47.7 \pm 7.2$ & TaqMan & A163G - G1181C & $\begin{array}{l}\text { WOMEN } \\
\text { MEN }\end{array}$ \\
\hline HUSSIEN et al., 2013 & CASE/CONTROL & $150 / 50$ & $57.3 \pm 3.9 / 57.3 \pm 3.9$ & PCR-RFLP & A163G & WOMEN \\
\hline JORGENSEN et al., 2004 & CASE/CONTROL & $107 / 206$ & DATA NO SHOWN & TaqMan & A163G & WOMEN \\
\hline KIM et al., 2007 & CASE/CONTROL & $222 / 163$ & $57.2 / 58.0$ & TaqMan & T245G - G1181C & WOMEN \\
\hline LANGDAHL et al, 2002 & CASE/CONTROL & $268 / 327$ & $30-82 / 20-82$ & TaqMan & A163G - G1181C - T245G - T950C & $\begin{array}{c}\text { WOMEN } \\
\text { MEN }\end{array}$ \\
\hline MENCEJ-BEDRAC et al., 2011 & CASE/CONTROL & $235 / 243$ & $61.5 \pm 8.3 / 64.4 \pm 8.2$ & PCR-RFLP & G1181C - T245G & WOMEN \\
\hline MENCEJ-BEDRAC et al., 2009 & CASE/CONTROL & $239 / 228$ & $64.5 \pm 8.2 / 61.5 \pm 8.3$ & TaqMan & G1181C & WOMEN \\
\hline PIEDRA et al., 2011 & CASE/CONTROL & $298 / 114$ & $59 \pm 13 / 62 \pm 13$ & TaqMan & A163G - G1181C - T245G & $\begin{array}{c}\text { WOMEN } \\
\text { MEN }\end{array}$ \\
\hline VIDAL et al., 2006 & CASE/CONTROL & $71 / 52$ & DATA NO SHOWN & TaqMan & G1181C - T950C & WOMEN \\
\hline YAMADA et al., 2003 & CASE/CONTROL & $1634 / 555$ & $46.2 \pm 0.4 / 46.3 \pm 0.2$ & FLUORESCENCE & T245G - T950C & WOMEN \\
\hline ZAVALA-CERNA et al., 2014 & CASE/CONTROL & $46 / 23$ & $49.9 / 49.9$ & PCR-RFLP & T245G - T950C & WOMEN \\
\hline ZHAO et al., 2005 & CASE/CONTROL & $134 / 71$ & $63.0 \pm 0.53 / 61.4 \pm 0.71$ & DIRECT SEQUENCING & G1181C & WOMEN \\
\hline
\end{tabular}


Table 2. Meta-analysis of association between polymorphisms in OPG gene and risk of Low Bone Mineral Density (allelic and genotypic comparisons).

\begin{tabular}{|c|c|c|c|c|c|c|c|c|c|c|c|c|c|c|}
\hline \multirow{2}{*}{ Variable } & \multirow{2}{*}{$\begin{array}{c}\text { Comparisons } \\
\text { (n) }\end{array}$} & \multirow{2}{*}{$\begin{array}{l}\text { Case/ } \\
\text { Control } \\
\text { (n) }\end{array}$} & \multicolumn{2}{|c|}{$m$ versus $M$} & \multicolumn{2}{|c|}{$M$ versus $m$} & \multicolumn{2}{|c|}{$\mathrm{mm}$ versus $\mathrm{Mm} / \mathrm{mm}$} & \multicolumn{2}{|c|}{ MM versus $\mathrm{Mm} / \mathrm{mm}$} & \multicolumn{2}{|c|}{ mm versus MM } & \multicolumn{2}{|c|}{$\mathrm{mm}$ versus $\mathrm{Mm}$} \\
\hline & & & OR (95\% Cl) & $p$ & OR $(95 \% \mathrm{Cl})$ & $p$ & OR $(95 \% \mathrm{Cl})$ & $P$ & OR $(95 \% \mathrm{Cl})$ & $p$ & OR $(95 \% \mathrm{Cl})$ & $P$ & OR $(95 \% \mathrm{Cl})$ & $p$ \\
\hline \multicolumn{15}{|l|}{ A163G } \\
\hline Overall & 10 & $1652 / 2010$ & $0.77(0.67,0.89)$ & 0.0003 & $1.27(1.10,1.46)$ & 0.0010 & $0.83(0.71,0.97)$ & 0.02 & $1.33(0.96,1.84)$ & 0.09 & $0.58(0.36,0.92)$ & 0.02 & $0.82(0.70,0.96)$ & 0.01 \\
\hline Mixed & 5 & $841 / 883$ & $0.71(0.59,0.85)$ & 0.0002 & $1.41(1.18,1.69)$ & 0.0002 & $0.65(0.52,0.82)$ & 0.0003 & $3.13(1.50,6.54)$ & 0.002 & $0.44(0.24,0.79)$ & 0.007 & $0.70(0.55,0.90)$ & 0.004 \\
\hline Asian & 1 & $285 / 290$ & $1.37(0.98,1.90)$ & 0.06 & $0.73(0.53,1.02)$ & 0.06 & $1.28(0.88,1.85)$ & 0.20 & $0.30(0.10,0.94)$ & 0.04 & $3.41(1.09,10.62)$ & 0.03 & $1.15(0.78,1.69)$ & 0.48 \\
\hline \multicolumn{15}{|l|}{ G1181C } \\
\hline Overall & 11 & $2307 / 2336$ & $1.25(1.14,1.37)$ & $<0.00001$ & $0.80(0.73,0.88)$ & $<0.00001$ & $1.19(1.04,1.36)$ & 0.01 & $0.79(0.69,0.91)$ & 0.001 & $1.40(1.18,1.67)$ & 0.001 & $1.19(1.02,1.39)$ & 0.03 \\
\hline Mixed & 1 & 211/154 & $1.06(0.78,1.43)$ & 0.72 & $0.95(0.70,1.28)$ & 0.72 & $0.94(0.61,1.44)$ & 0.77 & $0.76(0.45,1.29)$ & 0.31 & $1.20(0.67,2.16)$ & 0.53 & $0.84(0.53,1.34)$ & 0.47 \\
\hline Caucasian & 8 & $1589 / 1729$ & $1.12(1.01,1.23)$ & 0.04 & $0.90(0.81,0.99)$ & 0.04 & $1.10(0.93,1.30)$ & 0.26 & $0.82(0.71,0.96)$ & 0.01 & $1.23(1.01,1.51)$ & 0.04 & $1.04(0.87,1.25)$ & 0.67 \\
\hline Asian & 3 & $507 / 453$ & $1.36(1.13,1.65)$ & 0.001 & $0.73(0.61,0.89)$ & 0.001 & $1.38(1.09,1.74)$ & 0.008 & $0.59(0.39,0.91)$ & 0.02 & $1.86(1.20,2.89)$ & 0.006 & $1.29(1.00,1.65)$ & 0.05 \\
\hline \multicolumn{15}{|l|}{$\mathrm{T} 245 \mathrm{G}$} \\
\hline Mixed & 2 & $288 / 206$ & $1.17(0.78,1.76)$ & 0.44 & $0.85(0.57,1.28)$ & 0.44 & $1.19(0.76,1.84)$ & 0.45 & $1.38(0.33,5.67)$ & 0.66 & $0.73(0.18,3.00)$ & 0.66 & $0.96(0.68,1.35)$ & 0.82 \\
\hline Caucasian & 5 & $1106 / 1351$ & $0.78(0.58,1.06)$ & 0.11 & $1.28(0.94,1.72)$ & 0.11 & $0.78(0.57,1.08)$ & 0.13 & $1.72(0.41,7.19)$ & 0.46 & $0.57(0.14,2.39)$ & 0.44 & $0.80(0.58,1.10)$ & 0.17 \\
\hline Asian & 2 & $1040 / 439$ & $0.78(0.60,1.02)$ & 0.07 & $1.28(0.98,1.68)$ & 0.07 & $0.78(0.58,1.04)$ & 0.09 & $2.04(0.45,9.17)$ & 0.35 & $0.44(0.04,4.92)$ & 0.51 & $0.79(0.59,1.06)$ & 0.12 \\
\hline \multicolumn{15}{|l|}{ T950C } \\
\hline Overall & 5 & 1086/1772 & $1.44(0.97,2.14)$ & 0.07 & $0.72(0.51,1.02)$ & 0.07 & $1.61(0.93,2.79)$ & 0.09 & $0.69(0.45,1.06)$ & 0.09 & $1.04(0.82,1.33)$ & 0.74 & $1.42(0.88,2.28)$ & 0.15 \\
\hline Mixed & 1 & $65 / 51$ & $2.00(1.18,3.39)$ & 0.01 & $0.50(0.30,0.85)$ & 0.01 & $3.35(1.48,8.44)$ & 0.005 & $0.60(0.24,1.47)$ & 0.26 & $3.68(1.22,11.04)$ & 0.02 & $3.47(1.38,8.70)$ & 0.008 \\
\hline Caucasian & 3 & $742 / 905$ & $1.04(0.89,1.22)$ & 0.60 & $0.96(0.82,1.12)$ & 0.60 & $0.97(0.75,1.24)$ & 0.80 & $0.87(0.67,1.12)$ & 0.27 & $0.97(0.75,1.24)$ & 0.80 & $1.08(0.80,1.47)$ & 0.61 \\
\hline Asian & 1 & 279/816 & $0.99(0.82,1.21)$ & 0.94 & $1.01(0.83,1.23)$ & 0.94 & $1.00(0.76,1.33)$ & 0.99 & $1.03(0.72,1.48)$ & 0.87 & $0.98(0.65,1.46)$ & 0.91 & $1.01(0.75,1.37)$ & 0.94 \\
\hline
\end{tabular}

OR = Odds Ratio, $m=$ wild type allele, $M=$ mutant allele, Mixed = American and Others ethnicities . 
vated heterogeneity, $\mathrm{G}$ allele and risk of low bone mineral density in this polymorphism evidenced association with case group $(\mathrm{OR}=1.25,95 \% \mathrm{Cl} 1.14$, 1.37, $P<0.00001)$ (Figure 2-B). In other hand, $C$ allele was associated to control group (OR $=0.80$, $95 \% \mathrm{Cl} 0.73,0.88, P<0.00001)$ in ten studies as well as in evaluation of $G$ allele. Table 2 brings the combinations between genotypes in G1181 polymorphism.

\section{Association between T950C polymorphism and risk of low bone mineral density}

To evaluate the association between $\mathrm{T}$ and $\mathrm{C}$ alleles in this polymorphism the Random-effect statis- tical model was used because only five studies evaluating the T950C polymorphism and low bone mineral density were identified, these total two studies $[26,28]$ carried out elevated heterogeneity. If they had been excluded a few number of studies (three) could invalidate the meta-analysis. Therefore, $T$ allele was no significantly associated to case group (OR $=1.44,95 \% \mathrm{Cl} 0.97,2.14, P=0.07$ ) (Figure 3-A) and $C$ allele also was no significantly associated to control group $(\mathrm{OR}=0.72,95 \% \mathrm{Cl} 0.51,1.02, P=$ 0.07). The table 2 brings the genotype combinations to T950C polymorphism. With this statistical model used is not possible to build funnel plot.

Figure 3: (A) Meta-analysis of T allele in T950C polymorphism. (B) Meta-analysis of G allele in T245G polymorphism.

A

\begin{tabular}{|c|c|c|c|c|c|c|c|}
\hline Study or Subgroup & \multicolumn{2}{|c|}{ Experimental } & \multicolumn{2}{|c|}{ Control } & Weight & $\begin{array}{c}\text { Odds Ratio } \\
\text { M-H, Random, } 95 \% \mathrm{Cl}\end{array}$ & $\begin{array}{c}\text { Odds Ratio } \\
\mathrm{M}-\mathrm{H}, \text { Random, } 95 \% \mathrm{Cl}\end{array}$ \\
\hline Brandstrom et al., 2004 & 303 & 590 & 507 & 994 & $21.5 \%$ & $1.01[0.83,1.24]$ & 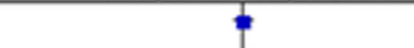 \\
\hline Langdhal et al., 2002 & 268 & 532 & 280 & 578 & $21.1 \%$ & $1.08[0.85,1.37]$ & 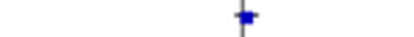 \\
\hline Vidal et al., 2006 & 223 & 362 & 77 & 238 & $19.5 \%$ & $3.35[2.38,4.73]$ & $=$ \\
\hline Yamada et al., 2003 & 333 & 558 & 977 & 1632 & $21.6 \%$ & $0.99[0.82,1.21]$ & \\
\hline Zavala-Cerna et al., 2014 & 82 & 130 & 47 & 102 & $16.2 \%$ & $2.00[1.18,3.39]$ & $\varpi$ \\
\hline Total $(95 \% \mathrm{Cl})$ & & 2172 & & 3544 & $100.0 \%$ & $1.44[0.97,2.14]$ & \\
\hline Total events & 1209 & & 1888 & & & & \\
\hline $\begin{array}{l}\text { Heterogeneity: } \mathrm{Tau}^{2}=0.1 \\
\text { Test for overall effect: } Z=\end{array}$ & $\begin{array}{l}\mathrm{Chi}^{2}=44 \\
81(\mathrm{P}=0\end{array}$ & $\begin{array}{l}32, d f= \\
7)\end{array}$ & $4(P<0 . C$ & $00001) ;$ & $I^{2}=91 \%$ & & 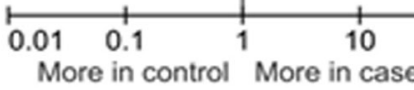 \\
\hline
\end{tabular}

B

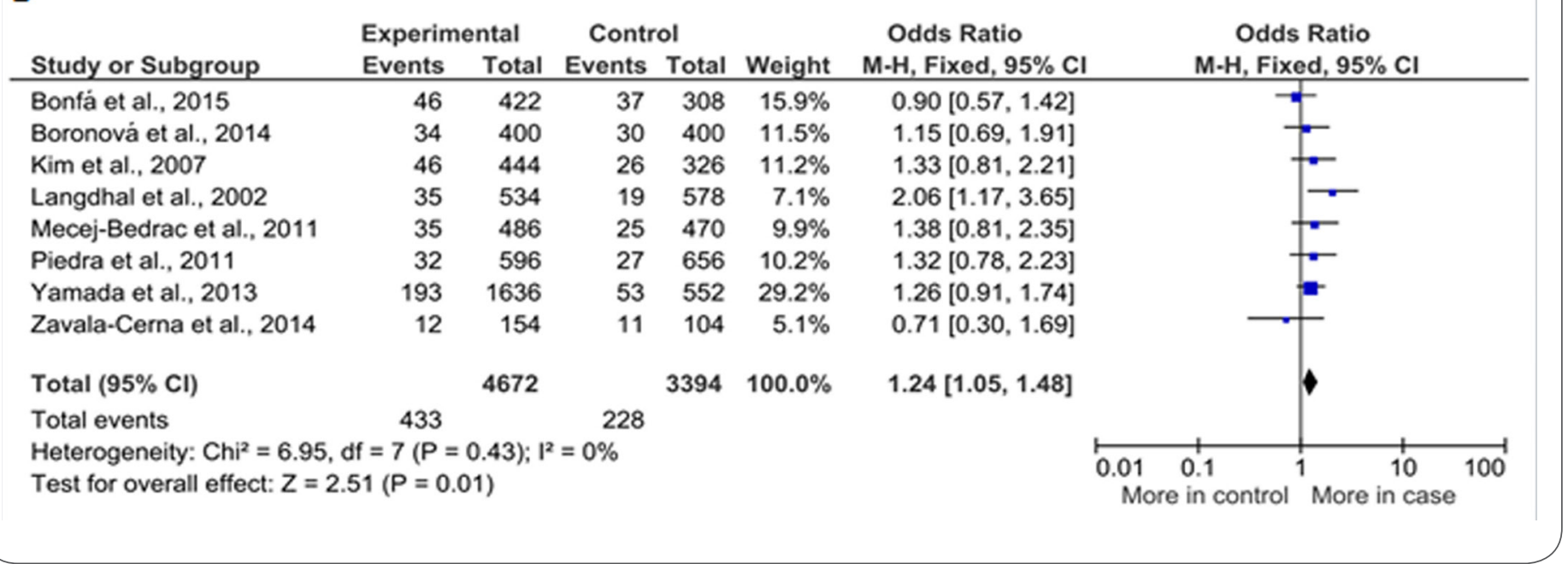




\section{Association between T245G polymorphism and risk of low bone mineral density}

Ten studies evaluated the T245G polymorphism and risk of low BMD, nevertheless, in evaluation of alleles two studies $[15,18]$ were excluded because elevated heterogeneity. Thus, eight papers composed the meta-analysis of alleles in which $\mathrm{T}$ allele was associated to control group (OR $=0.80,95 \% \mathrm{Cl}$ $0.68,0.95, P=0.01)$ and $G$ allele was significantly associated to case group (OR $=1.24,95 \% \mathrm{Cl} 1.05$, $1.48, P=0.01$ ) (Figure 3-B). The combinations of genotypes in T245G polymorphism also were analyzed (Table 2).

\section{Sensitivity analysis and Publication bias}

To evaluate the individual effect of studies a sensitivity analysis was performed by omitting each study to assess this impact on pooled ORs. No single publication changed the pooled ORs qualitatively, which suggested that results of this meta-analysis were accurate. The Funnel plots available by statistical software did not reveal any indication of publication bias as showed in figures 4-A, B, and C.

\section{Discussion}

OPG is an important mediator of bone remodeling by neutralizing the effects of RANKL with inhibition of osteoclast-differentiation [30]. Several candidate genes for different calciotropic factors known to regulate bone remodeling and variations in these genes can cause changes in bone physiology [11] and a genome-wide study cited the association between polymorphisms in Osteoprotegerin gene and clinical conditions such as osteoporosis [31].

The A163G polymorphism in OPG gene is a mutation occurred in the $5^{\prime}$ flanking region related to risk of fractures and associated to strong linkage disequilibrium with other single nucleotide polymorphisms sites [22]. In this meta-analysis the $\mathrm{G}$ allele was associated to patients case group evidenced its role in risk of low bone mineral density. This result contradicts the Choi et al. [32] findings in which A163G polymorphism was not significantly associated to variations in Bone Mass Density.

The A allele was associated to control group (OR $=0.77,95 \% \mathrm{Cl} 0.67,0.89, P=0.0003)$, the results found in meta-analysis of this polymorphism is according with Jørgensen et al. [20]. However the study carried out by Takács et al. [33] showed this polymorphism was not in linkage disequilibrium with rs1564858 SNP, and in this study, A allele has been significantly associated to low bone mineral density as well as the AA and AG genotypes.

In other hand, Langdhal et al. [22], in their study, proved the linkage between A163G polymorphism and G1181C polymorphism, this fact may explain why A allele was associated to control group and $G$ allele was associated to patients case group, whether observed that most of studies included in meta-analysis evaluated these two polymorphism in same patients (Table 1).

In evaluation of G1181C polymorphism the results showed elevated association with $C$ allele and control group. This data corroborates evidences in which G1181C polymorphism as well as CC genotype was associated to normal BMD in Korean patients with Adolescent Idiopathic Scoliosis [34]. A previous study demonstrated $\mathrm{G}$ allele and $\mathrm{GG}$ genotype carried out a bone mineral density $3.7 \%$ lower in women than women with CC genotype [35].

The $G$ allele increased risk of low bone mineral density in postmenopausal women when associated to T950C polymorphism and other SNP (rs4876869) as haplotype [36]. This allele and GG genotype were not associated with BMD variations in postmenopausal Mexican-Mestizo women [37] corroborating data presented in this meta-analysis (Table 2). Nevertheless the stratified evaluation in this polymorphism in mixed population showed data from only one study, so this result must be considered with caution.

The T950C polymorphism was not associated 
Figure 4: Funnel plots of comparision $G$ allele versus $A$ allele in $A 163 G$ polymorphism $(A), G$ allele versus $C$ allele in $\mathrm{G} 1181 \mathrm{C}$ polymorphism (B), and $\mathrm{G}$ allele versus $\mathrm{T}$ allele in T245G polymorphism (C).

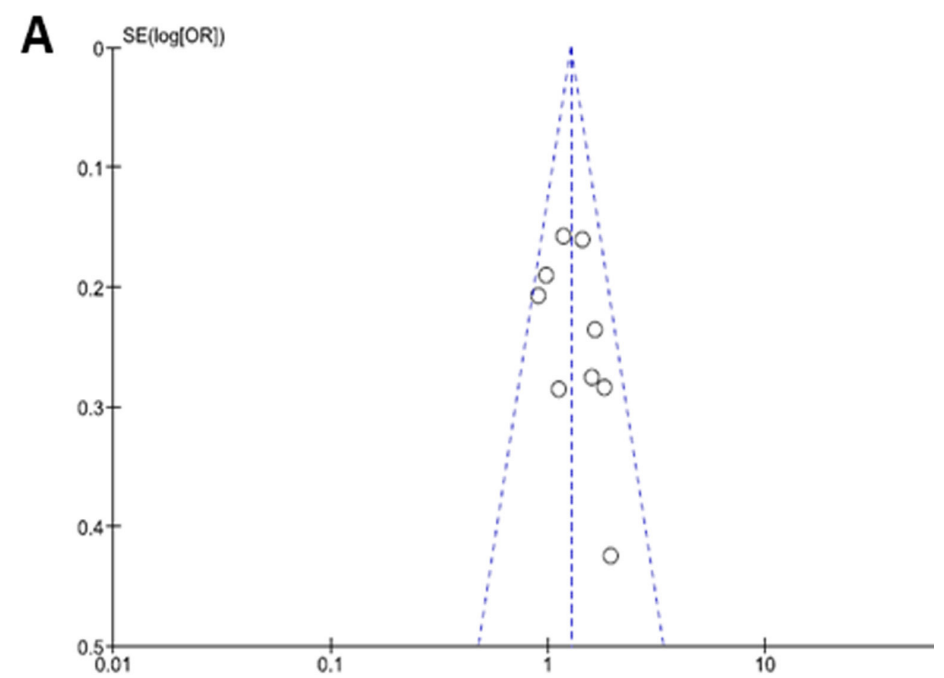

B

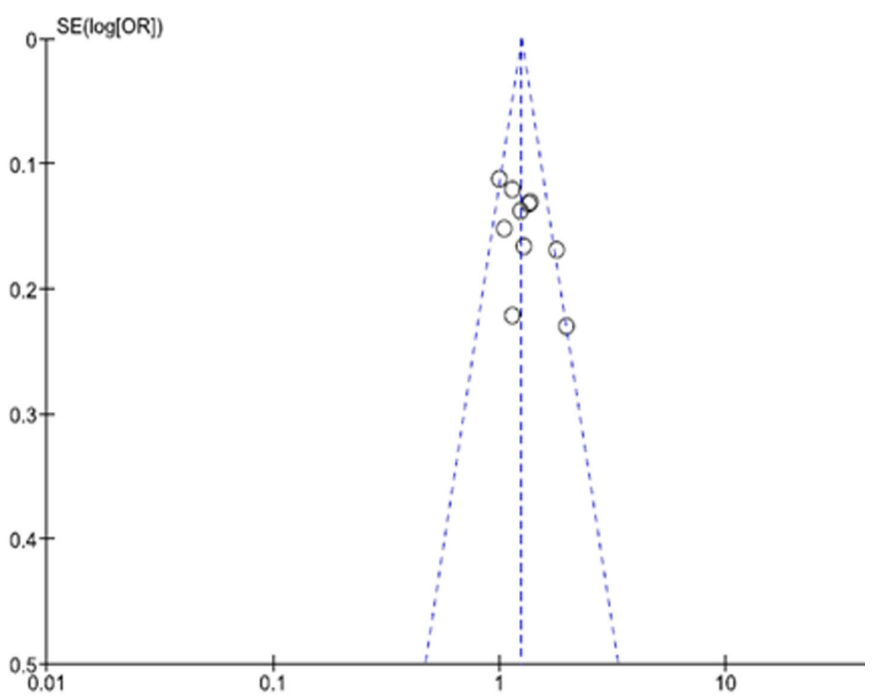

C

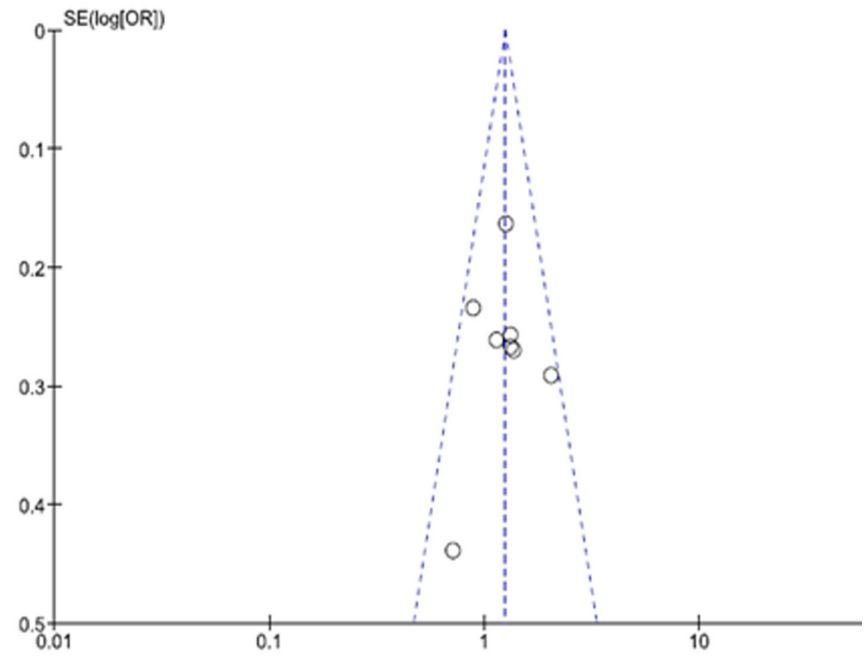


to case group neither control group. These contradicting results can be explained by strong linkage disequilibrium observed in this polymorphism with A163G, G1181C and T245G polymorphism as reported in others studies [22]. T950C polymorphism also was not associated to risk of fracture in elderly Australian women [11] but was associated to variations in BMD in premenopausal women [38].

In stratified analysis by ethnicity showed small variation in OR values. Analysis in Asian ethnicity evidenced a few number of studies, it brings insufficient data about this population resulting in undue conclusions about the influence of these polymorphisms in Asian population.

The association between $G$ allele in T245G polymorphism and bone low density also was showed by this meta-analysis. $G$ allele was identified as a factor associated to decreased of bone mineral density in Korean women when in linkage disequilibrium with A163G polymorphism, although this polymorphism or any combination genotype did show associated to variations in serum OPG levels [39].

The meta-analysis presented in these results had some limitations.

First, most of studies addressed the polymorphisms evaluated in women, specifically (Table 1). The menopause is a condition that accelerates osteoclast activation enhancing the risk of osteoporosis and so low bone mineral density [40] and affects the women. The majority of patients are female, the results could the results may be biased to womankind. The small numbers of studies evaluating the polymorphism in men was insufficiently to perform a separate analysis based in gender.

Second, the limited data about ethnicity prevents an stratified analysis is made so disregarding factors that lead to better understanding of these polymorphism and low bone mineral density.

Lastly, currently there are many evidences of the relationship between genetic changes and the development of diseases. Two main types of studies are used to assess this relationship: studies to identify chromosomal regions and polymorphisms studies [41], the latter being more efficient for the detection of genetic diseases that contributions into complex binding studies [42].

Another type of study that can be conducted to assess the interaction between polymorphisms and certain disease is the meta-analysis because from a systematic combination of results of individual studies meta-analysis increases the association of detection capability between factors presenting advantage by overcoming the shortcomings of individual research [43]. Despite such advantages, the meta-analysis does not evaluate polymorphism when identified total linkage disequilibrium.

Although this limitations that could represent bias, no bias of publications was showed by funnel plots validating the results.

\section{Conclusion}

This meta-analysis evaluated four polymorphisms (A163G, G1181C, T950C, T245G) in 5,120 patients with low bone mineral density and 4,386 controls showed significant association among $G$ alleles in A163G, G1181C and T245G polymorphism, respectively, and increased risk of low bone mineral density, in complement T950C polymorphism was not significantly associated to risk of low BMD.

\section{Acknowledgments}

Research supported by the Federal University of Piaui (UFPI - Edital PIBIC 2013/2014 and BIAMA 03/2014). We thank teacher Abilio Borghi for the grammar review of the manuscript.

\section{Conflict of Interest}

The authors declare that they have no conflict of interests. 


\section{Rerefences}

1. Gnudi S, Sitta E, Fiumi N: Relationship between body composition and bone mineral density in women with and without osteoporosis: relative contribution of lean and fat mass. J Bone Miner Metab 2007, 25(5):326.

2. Jian WX, Long JR, Li MX, Liu XH, Deng HW: Genetic determination of variation and covariation of bone mineral density at the hip and spine in a Chinese population. J Bone Miner Metab 2005, 23(2):181-185.

3. Hussien YM, Shehata A, Karam RA, Alzahrani SS, Magdy $\mathrm{H}$, El-Shafey AM: Polymorphism in vitamin $D$ receptor and osteoprotegerin genes in Egyptian rheumatoid arthritis patients with and without osteoporosis. Mol Biol Rep 2013, 40:36753680.

4. Panach L, Mifsut D, Tarín JJ, Cano A, García-Pérez MÁ: Replication study of three functional polymorphisms associated with bone mineral density in a cohort of Spanish women. J Bone Miner Metab 2014, 32(6):691-698.

5. Horst-Sikorska W, Kalak R, Wawrzyniak A, Marcinkowska M, Celczynska-Bajew L, Slomski R: Association analysis of the polymorphisms of the VDR gene with bone mineral density and the occurrence of fractures. J Bone Miner Metab 2007, 25(5):310-319.

6. Yu F, Huang X, Miao J, Guo L, Tao D: Association between osteoprotegerin genetic variants and osteoporosis in Chinese postmenopausal women. Endocr J 2013, 60(12):1303-1307.

7. Nakashima T, Takayanagi $\mathrm{H}$ : Osteoclasts and the immune system. J Bone Miner Metab 2009, 27(5):519-529.

8. Wu ZZ, Liu M: The effect of low-body weight combined with T149C and A163G polymorphism of osteoprotegerin promoter region on osteoporosis. Chin J Geriatr 2006, 25:645-650.

9. Shui MM, Na SP, Xie RJ, Wang MG, Mu SH: Relationship between the polymorphisms of $\mathrm{T} 149 \mathrm{C}$ and $\mathrm{T} 950 \mathrm{C}$ in osteoprotegerin gene and the glucocorticoid-induced osteoporosis. Chin J Blood Purif 2008, 17:375-379.

10. Tu P, Duan $P$, Zhang RS, Xu DB, Wang $Y$, Wu HP, et al: Polymorphisms in genes in the RANKL/RANK/OPG pathway are associated with bone mineral density at different skeletal sites in post-menopausal women. Osteoporos Int 2015, 26(1):179-185.

11. Ueland T, Bollerslev J, Wilson SG, Dick IM, Islam FMA, Mullin $\mathrm{BH}$, et al: No associations between OPG gene polymorphisms or serum levels and measures of osteoporosis in elderly Australian women. Bone 2007, 40(1):175-181.

12. Bonfá AC, Seguro LPC, Caparbo V, Bonfá E, Pereira RMR: RANKL and OPG gene polymorphisms: associations with vertebral fractures and bone mineral densityin premenopausal systemic lupus erythematosus. Osteoporos Int 2015, 26(5):1563-1571.

13. Boroňová I, Bernasovská J, Kl'oc J, Tomková Z, Petrejčíková E, Mačeková S, et al: Analysis of OPG Gene Polymorphism T245G (rs3134069) in Slovak Postmenopausal Women. World Acad Sci
Eng Technol 2014, 8(9).

14. Boroňová I, Bernasovská J, Kl'oc J, Tomková Z, Petrejčíková E, Gabriková D, et al: TNFRSF11B Gene Polymorphisms A163G and G11811C in Prediction of Osteoporosis Risk. World Acad Sci Eng Technol 2014, 8(1).

15. Boroňová I, Bernasovská J, Mačeková S, Petrejčíková E, Tomková Z, Kl'oc J, et al: TNFRSF11B gene polymorphisms, bone mineral density, and fractures in Slovak postmenopausal women. J Appl Genetics 2015, 56(1):57-63.

16. Brambila-Tapia AJL, Durán-González J, Sandoval-Ramírez L, Mena JP, Salazar-Páramo M, Gámez-Nava Jl, et al: MTHFR C677T, MTHFR A1298C, and OPG A163G polymorphisms in Mexican patients with rheumatoid arthritis and osteoporosis. Dis Markers 2012, 32:109-114.

17. Brändström H, Gerdhem P, Stiger F, Obrant KJ, Melhus $H$, Ljunggren $\mathrm{O}$, et al: Single Nucleotide Polymorphisms in the Human Gene for Osteoprotegerin are Not Related to Bone Mineral Density or Fracture in Elderly Women. Calcif Tissue Int 2004, 74:18-24.

18. Dincel E, Sepici-Dincel A, Sepici V, Ozsoy H, Sepici B: Hip fracture risk and different gene polymorphisms in the Turkish population. Clinics (São Paulo) 2008, 63(5):645-650.

19. Hsu YH, Niu T, Terwedow HA, Xu X, Feng Y, Li Z, et al: Variation in genes involved in the RANKL/RANK/OPG bone remodeling pathway are associated with bone mineral density at different skeletal sites in men. Hum Genet 2006, 118: 568-577.

20. Jørgensen $\mathrm{HL}$, Kusk $P$, Madsen B, Fenger M, Lauritzen JB: Serum osteoprotegerin (OPG) and the $\mathrm{A} 163 \mathrm{G}$ polymorphism in the OPG promoter region are related to peripheral measures of bone mass and fracture odds ratios. J Bone Miner Metab 2004, 22:132-138.

21. Kim JG, Kim JH, Kim JY, Ku SY, Jee BC, Suh CS, et al: Association between osteoprotegerin (OPG), receptor activator of nuclear factor-JB (RANK), and RANK ligand (RANKL) gene polymorphisms and circulating OPG, soluble RANKL levels, and bone mineral density in Korean postmenopausal women. Menopause 2007, 14(5):913-918.

22. Langdahl BL, Carstens M, Stenkjaer L, Eriksen EF: Polymorphisms in the Osteoprotegerin Gene Are Associated With Osteoporotic Fractures. J Bone Miner Res 2002, 17(7):1245-1255.

23. Mencej-Bedrac S, Prezelj J, Kocjan T, Teskac K, Ostanek B, Smelcer $M$, et al: The combinations of polymorphisms in vitamin D receptor,osteoprotegerin and tumour necrosis factor superfamily member 11 genes are associated with bone mineral density. J Mol Endocrinol 2009, 42:239-247.

24. Mencej-Bedrač S, Preželj J, Marc J: TNFRSF11B gene polymorphisms $1181 \mathrm{G}>\mathrm{C}$ and $245 \mathrm{~T}>\mathrm{G}$ as well as haplotype $\mathrm{CT}$ influence bone mineral density in postmenopausal women. Maturitas 2011, 69:263- 267.

25. Piedra M, García-Unzueta MT, Berja A, Paule B, Lavín BA, Valero $C$, et al: Single nucleotide polymorphisms of the OPG/ RANKL system genes in primary hyperparathyroidism and their 
relationship with bone mineral density. BMC Med Genet 2011, 12:168

26. Vidal C, Brincat $M$, Xuereb Anastasi A: TNFRSF11B gene variants and bone mineral density in postmenopausal women in Malta. Maturitas 2006, 53:386-395.

27. Yamada $Y$, Ando F, Niino N, Shimokata H: Association of polymorphisms of the osteoprotegerin gene with bone mineral density in Japanese women but not men. Mol Genet Metab 2003, 80: 344-349.

28. Zavala-Cerna MG, Moran-Moguel MC, Cornejo-Toledo JA, Gonzalez-Montoya NG, Sanchez-Corona J, Salazar-Paramo M, et al: Osteoprotegerin Polymorphisms in a Mexican Population with Rheumatoid Arthritis and Generalized Osteoporosis: A Preliminary Report. J Immunol Res 2015, 2015.

29. Zhao HY, Liu JM, Ning G, Zhao YJ, Zhang LZ, Sun LH, et al: The influence of Lys3Asn polymorphism in the osteoprotegerin gene on bone mineral density in Chinese postmenopausal women. Osteoporos Int 2005, 16: 1519-1524.

30. Bergström I, Parini P, Gustafsson SA, Andersson G, Brinck J: Physical training increases osteoprotegerin in postmenopausal women. J Bone Miner Metab 2012, 30(2):202-207.

31. Richards JB, Rivadeneira F, Inouye M, Pastinen TM, Soranzo $\mathrm{N}$, Wilson SG, et al: Bone mineral density, osteoporosis, and osteoporotic fractures: a genome-wide association study. Lancet 2008, 371:1505-1512.

32. Choi JY, Shin A, Park SK, Chung HW, Cho SI, Shin CS, et al: Genetic Polymorphisms of OPG, RANK, and ESR1, and Bone Mineral Density in Korean Postmenopausal Women. Calcif Tissue Int 2005, 77:152-159.

33. Takács I, Lazáry A, Kósa JP, Kiss J, Balla B, Nagy Z, et al: Allelic variations of RANKL/OPG signaling system are related to bone mineral density and in vivo gene expression. Eur J Endocrinol 2010, 162(2):423-431.

34. Eun IS, Park WW, Suh KT, Kim JI, Lee JS: Association between osteoprotegerin gene polymorphism and bone mineral density in patients with adolescent idiopathic scoliosis. Eur Spine J 2009, 18:1936-1940.

35. Moffett SP, Oakley JI, Cauley JA, Lui LY, Ensrud KE, Taylor BC, et al: Osteoprotegerin Lys3Asn Polymorphism and the Risk of Fracture in Older Women. J Clin Endocrinol Metab 2008, 93(5):2002-2008.

36. Vidal C, Formosa R, Xuereb-Anastasi A: Functional polymorphisms within the TNFRSF11B (osteoprotegerin) gene increase the risk for low bone mineral density. J Mol Endocrinol 2011, 47(3):327-333.

37. Rojano-Mejía D, Coral-Vázquez RM, Espinosa LC, RomeroHidalgo S, López-Medina G, García Mdel C, et al: TNFRSF11B gene haplotype and its association with bone mineral density variations in postmenopausal Mexican-Mestizo women. Maturitas 2012, 71(1):49-54.
38. Wynne F, Drummond F, O'sullivan K, Daly M, Shanahan F, Molloy MG, et al: Investigation of the genetic influence of the OPG, VDR (Fok1), and COLIA1 Sp1 polymorphisms on BMD in the Irish population. Calcif Tissue Int 2002, 71:26-35.

39. Yun EJ, Rhee EJ, Lee WY, Baek KH, Kang MI, Park CY, et al: Osteoprotegerin genetic polymorphism of the main Korean menopausal women Impact on bone metabolismo. J Kor Soc Endocrinol 2005, 20(3):204-215.

40. Rosen CJ, Bouxsein ML: Mechanisms of Disease: is osteoporosis the obesity of bone? Nat Clin Pract Rheumatol 2006, 2(1):3543.

41. Risch NJ: Searching for genetic determinants in the new millennium. Nature 2000, 405(6788):847-856.

42. Chen Z, Tang NLS, Cao X, Qiao D, Yi L, Cheng JCY, et al: Promoter polymorphism of matrilin-1 gene predisposes to adolescente idiopathic scoliosis in a Chinese population. Eur J Hum Genet 2008, 17(4):525-532.

43. Zeggini E, Ioannidis, JPA: Meta-analysis in genome-wide association studies. Pharmacogenomics 2009, 10(2):192-201.

\section{Comment on this article:}

\section{$4[8$ in $8+\mathbf{S} P$}

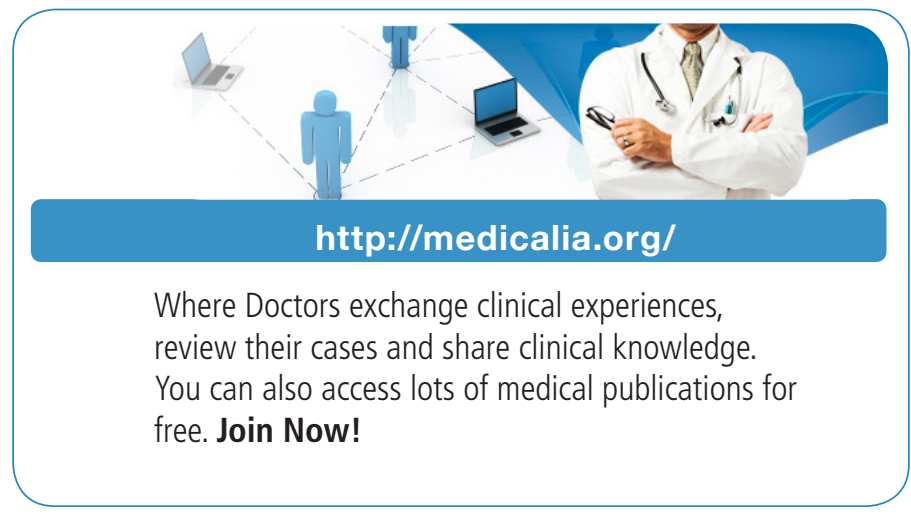

Publish with iMedPub

http://www.imed.pub

International Archives of Medicine is an open access journal publishing articles encompassing all aspects of medical science and clinical practice. IAM is considered a megajournal with independent sections on all areas of medicine. IAM is a really international journal with authors and board members from all around the world. The journal is widely indexed and classified Q1 in category Medicine. 